\title{
Three-Dimensional Reconstruction and Quantitative Study of a Pyramidal Cell of a Cajal Histological Preparation
}

\author{
Pablo García-López, Virginia García-Marín, and Miguel Freire \\ Museo Cajal, Instituto Cajal, Consejo Superior de Investigaciones Cientificas, 28002 Madrid, Spain
}

\begin{abstract}
The year 2006 marks the centenary of the Nobel Prize for Physiology or Medicine awarded to Santiago Ramón y Cajal and Camilo Golgi. We commemorate this centenary with a three-dimensional reconstruction and a quantitative study of a pyramidal cell of a Cajal's histological preparation. This preparation is one of the 4529 histological preparations personally made by Ramón y Cajal and preserved in the Museum Cajal. The three-dimensional reconstruction of the neuron allows visualizing one important discovery of Ramón y Cajal that constitutes an active field of research in present-day neuroscience: dendritic spines.
\end{abstract}

Key words: Cajal; pyramidal cell; dendritic spines; filopodia; 3D reconstruction; Golgi method

Dendritic spines were discovered by Santiago Ramón y Cajal in 1888, in his first article published with the Golgi Method "... the surface ... appears bristling with thorns or short spines." This is the first reference to dendritic spines in his work, but it is not the only one. He also made important observations that are still topics of research. These include the distribution of dendritic spines along the neuronal tree (Ramón y Cajal, 1891), the dependence of spine density and size on the area and the species (Ramón y Cajal, 1896a, 1899), and the larger size of dendritic appendages during development (Ramón y Cajal, 1889, 1933). Ramón y Cajal also proposed a physiological role for dendritic spines. In his opinion, dendritic spines served to increase the receptive surface (Ramón y Cajal, 1896a). He also accepted the hypothesis of Berkley (1895) that dendritic spines were the points at which axons connected and dis-

\footnotetext{
Received Aug. 16, 2006; revised Sept. 25, 2006; accepted Sept. 25, 2006 This work was supported by the Ramón Areces Foundation.

Correspondence should be addressed to Virginia García-Marín, Museo Cajal, Instituto Cajal, Consejo Superior de Investigaciones Cientificas, Avenida Doctor Arce 37, 28002 Madrid,Spain. E-mail: vgmarin@cajal.ssic.es.

DOI:10.1523/JNEUROSCI.3543-06.2006

Copyright $\odot 2006$ Society for Neuroscience $\quad$ 0270-6474/06/2611249-04\$15.00/0
}

charged nervous impulse: "Do they represent the lines of charge or absorption of nerve impulses, as stated by Berkley? The latter opinion appears plausible to us. It reconciles well with our idea, expressed in another publication, namely that by virtue of the spines, dendritic branches increase their receptive surface and establish closer contacts with the axonal terminal arborization" (Ramón y Cajal, 1899). Although the work of Gray (1959a,b) confirmed the hypothesis of Berkley, we still do not know the functional role of dendritic spines because excitatory synapses can also be made on dendritic shafts. It seems most likely that dendritic spines serve as biochemical compartments as has been proposed.

To reconstruct this Cajal neuron, we used an interactive light-microscope computer system for the three-dimensional (3D) reconstruction and did quantitative study of a neuron from layer III of young mouse cerebral cortex. Optic sections $(1280 \times 1024$ pixels $)$ were taken from the preparation using a digital camera (DXM1200; Nikon, Tokyo, Japan), a motorized stage (ProScan H128; Prior Scientific, Rockland, MA), and a light microscope (Nikon Eclipse E600) with an oil immersion objective $100 \times$, numerical aperture (NA) 1.4. The structures were coded as $3 \mathrm{D}$ coordinates of selected points using the program Neuronal Coding (Freire, 1992). With the program Neuronal Quantification, we measured the number of dendritic spines, their distance from the soma, and the sizes of the head and neck. Dendritic spines were classified as sessile, thin, mushroom, or branched spines. The code was converted with Persistence of Vision Raytracer (POV-Ray) for $3 \mathrm{D}$ rendering (Arellano and Freire, unpublished results)

The histological preparation (P80001) is a Golgi-impregnated slide from mouse cerebral cortex (Fig. 1). Because of the density and size of dendritic appendages, we can assume that the mouse was older than $20 \mathrm{~d}$. However, the preparation did not include the superior colliculus, a distinctive morphological feature of adult mouse. Thus, we only can conclude that the age of the mouse was between 20 and $45 \mathrm{~d}$. The three-dimensional reconstruction of the pyramidal cell is shown in Figure 2. A detail of the dendritic spines of the original preparation and their coding is shown in Figure 3. A movie of the neuron is shown in the supplemental data 
(available at www.jneurosci.org as supplemental material). The total number of dendritic spines and filopodia codified was 1563 .

\section{Distribution and density of dendritic spines}

Spines were absent from soma and the origin of thick dendrites, but their number increased with distance from soma. On the basilar branches on the first $46.5 \mu \mathrm{m}$, there was an increase of the mean number of spines from 2.64 spines/15.5 $\mu \mathrm{m}$ to 12.47 spines $/ 15.5 \mu \mathrm{m}$, after which the distribution reached a plateau. The maximum density 13.66 spines/15.5 $\mu \mathrm{m}$ was found on the interval $62-77.5 \mu \mathrm{m}$. On the apical trunk, there were only three spines until the third oblique branch. The oblique branches of the apical trunk and the branches of the apical tuft had a density of dendritic spines similar to the basilar branches.

\section{Size of dendritic spines and filopodia} The dendritic spines differed from filopodia especially in their size. The size of the pedunculated appendages was $1.43 \pm 0.6$ (mean \pm SD). Most $(81 \%)$ had a total length $<2 \mu \mathrm{m}, 14.36 \%$ had a length from 2 to $3 \mu \mathrm{m}$, and only $5.64 \%$ of pedunculated appendages had a length $>3 \mu \mathrm{m}$, which we considered to be filopodia. The sessile spines had a mean length of $0.42 \pm$ $0.21 \mu \mathrm{m}$.

\section{Head and neck size}

The range of the head size was (0.01-1.31 $\left.\mu \mathrm{m}^{2}\right)$. There was a great heterogeneity of sizes. The area for the head of the pedunculated appendages was $0.18 \pm 0.20$ (mean $\pm \mathrm{SD})$. The sessile spines had an area of $0.17 \pm 0.13$ (mean $\pm \mathrm{SD}$ ). The range of the neck length was from null length (sessile spines) to $4.2 \mu \mathrm{m}$, which corresponds to a filopodia. The mean was $0.90 \pm 0.51$. The range of the neck width was from 0.11 to $0.95 \mu \mathrm{m}$ (mean of $0.23 \pm$ $0.13)$.

\section{Dendritic appendages types}

We classified the appendages in dendritic spines (sessile, thin, mushroom, and, branched) and dendritic filopodia (Fig. $4)$. The different percentages were as follows: $64.7 \%$ thin, $16.8 \%$ sessile, $14.7 \%$ mushroom, $2.41 \%$ branched, and $1.39 \%$ dendritic filopodia. Few dendritic spines ended in an appendage or spinule. The distribution of these shapes did not follow any known pattern. The mushroom spines were sparsely distributed along the dendrites.

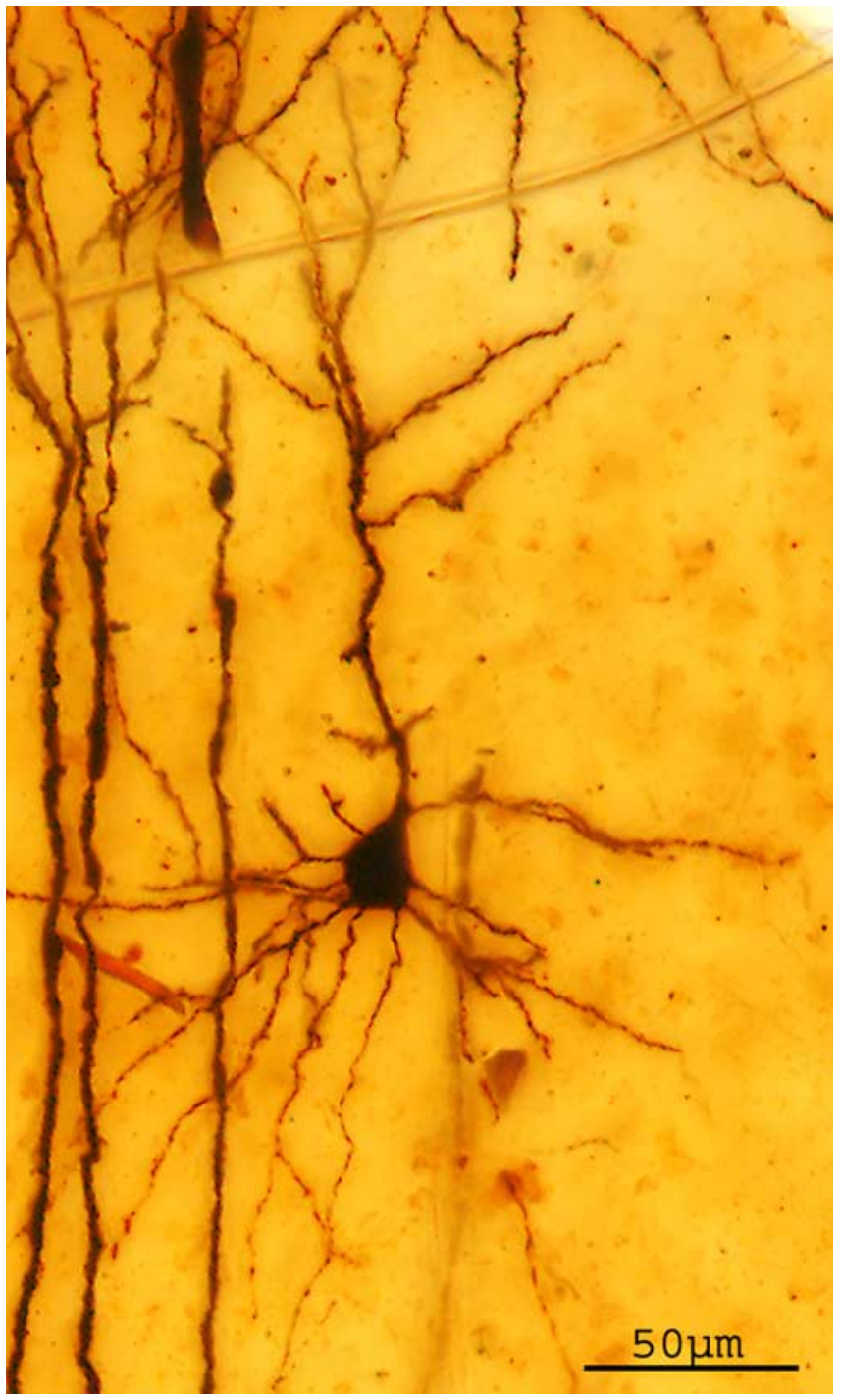

Figure 1. Layer III pyramidal cell of cerebral cortex of mouse from a original preparation of Santiago Ramón y Cajal impregnated with the Golgi method (P80001). Z-projection (32 sections; Z-step, $2.072 \mu \mathrm{m}$ ). Objective 20X, NA 0.75 (NIH ImageJ).

\section{Discussion}

Dendritic spines receive most of the excitatory impulses of a pyramidal cell, consistent with the information processing capacity of the neuron. The first correlation between the number of afferent fibers and the density of dendritic spines was made by Ramón y Cajal (1896a).

The distribution of dendritic spines follows a known pattern. The proximal portions of apical and basal dendrites generally are devoid of spines and excitatory synapses, but many symmetric (inhibitory) synapses are found (AlonsoNanclares et al., 2004). Ramón y Cajal (1896b) noted the lack of dendritic spines in the proximal portion of the dendrites and used it for proving that dendritic spines were real appendages and not silver nitrate precipitates.

The number of dendritic spines increases moving away from soma. In our analysis, the maximum density is lower than density found in human temporal cortex 14.19 spines/10 $\mu \mathrm{m}$ (BenavidesPiccione et al., 2002), as noted by Ramón y Cajal (1909): "They vary also with the animal species, and we may state in general terms, that a cell with spiny processes in homologous nuclei has more spines, the higher the level of the subject in the animal series. Thus, as an example in vertebrates, the Purkinje cell of birds shows fewer spines than that of mammals." It implicates a higher capacity to process information by the pyramidal cells of human cerebral cortex.

We found a great variability in the total length of pedunculated appendages. Most of them $(81 \%)$ have $<2 \mu \mathrm{m}$. There is a population of dendritic appendages (5.64\%) longer than $3 \mu \mathrm{m}$ that we considered as filopodia. The rest of the population $(14.36 \%)$ had an intermediate length 


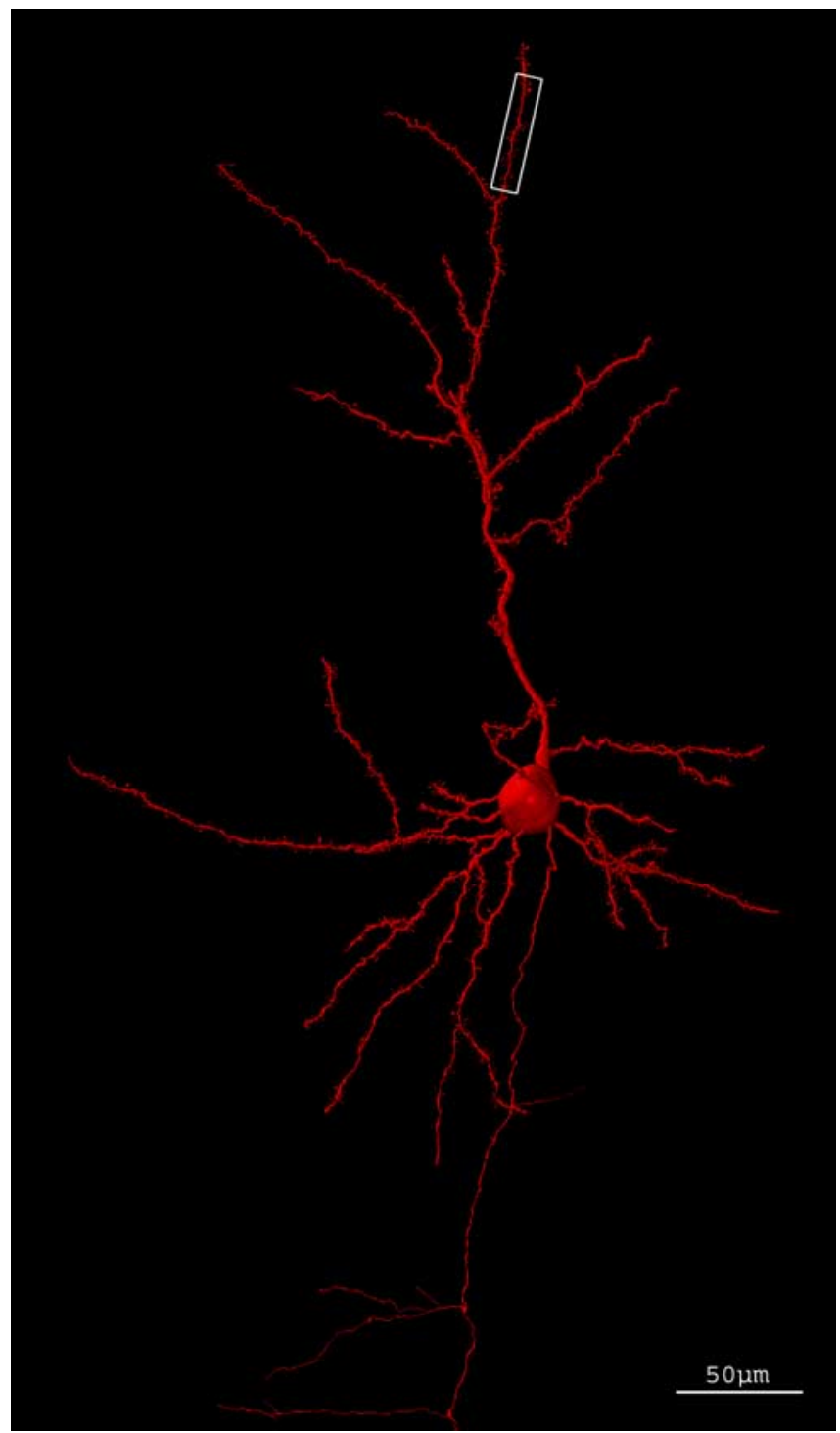

Figure 2. Three-dimensional reconstruction of a layer III pyramidal cell of cerebral cortex of mouse. Codification of the neuron with neuronal coding and rendered with POV-Ray. The white box outlines the fragment amplified in Figure $3 B$.

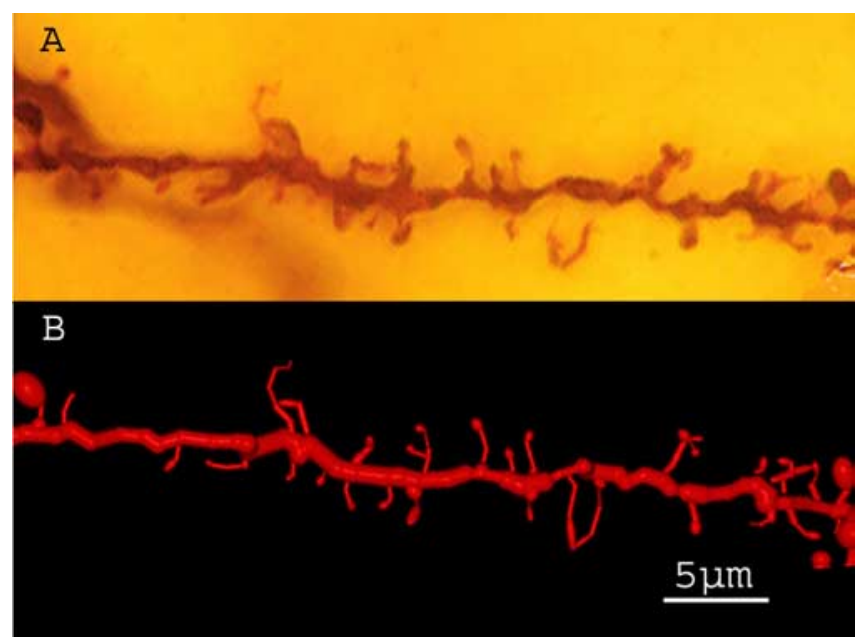

Figure 3. Fragment of an oblique apical branch with thin spines, mushroom spines, filopodia, and branched spines. $\boldsymbol{A}$, Z-projection (27 sections; $z$-step, $0.291 \mu \mathrm{m}$. Objective 100 X, NA 1.4. B, Three-dimensional reconstruction of the same segment.
(2-3 $\mu \mathrm{m})$; they could be filopodia transforming to dendritic spines (Daily and Smith, 1996).

In our data, the percentage of thin spines was $65 \%$. They had small heads (usually $<0.15 \mu \mathrm{m}^{2}$ ). One interesting issue is whether this population of thin dendritic spines makes stable and functional synapses to understand its synaptic plasticity. However, the strength of these synapses might be less powerful than those with big heads because the volume of the spine head is directly proportional to the size of the postsynaptic density (Freire, 1978), the size of the presynaptic terminal (Špaèek and Hartmann, 1983; Peters, 1987), the number of AMPA postsynaptic receptors (Nusser et al., 1998; Matsuzaki et al., 2001; Kasai et al., 2003), the presynaptic number of docked synaptic vesicles, and the ready available pool of neurotransmitters (Špaček and Hartmann, 1983; Harris and Stevens, 1989; Nusser et al., 1998; Schikorski and Stevens, 2001). In addition, small spines are more motile and unstable than bigger ones (Parnass et al., 2000; Grutzendler et al., 2002; Trachtenberg et al., 2002). Taking these observations, Kasai et al. (2003) proposed that large spines (mushroom and sessile spines) codify synaptic memory, whereas small spines (filopodia and thin spines) serve as a source to create new synapses (synaptic learning).

Our percentage of spine categories was comparable with other studies in hippocampus, cerebral cortex, and cerebellum of rats of different ages (Peters and Kaiserman-Abramof, 1970; Harris et al., 1992; Lee et al., 2004). These data suggest that the distribution of spine shapes is preserved in different cells and different areas. Recent experiments (Holtmat et al., 2005) have shown that the proportion of stable spines (usually mushroom) increases with age, whereas the proportion of unstable spines (usually thin spines) decreases with age. This change in dendritic spine stability with age might have functional consequences for the maturation of the neuron such as a reduction in synaptic plasticity.

We are beginning to understand the dendritic spine types in terms of its functional activity. Small spines could be "transient" and contribute to weak synaptic connections, whereas large spines could be "persistent" and contribute to strong synaptic connections. In the pyramidal neuron we studied, the percentage $(66.7 \%)$ of small spines, thin type was bigger than the percentage $(15.1 \%)$ of large spines, mushroom type. This could mean 
that the studied neuron was involved in a few stable circuits and retained most of its plastic or learning capabilities. Again, it is interesting to return to Ramón y Cajal (1894), recalling that he introduced the term plasticity more than a century ago: “... Similar plasticity of the cellular expansions varies, probably at different ages: great in the young, it lowers in the adult and almost disappears in the ancient."

\section{References}

Alonso-Nanclares L, White EL, Elston GN, DeFelipe J (2004) Synaptology of the proximal segment of pyramidal cell basal dendrites. Eur J Neurosci 19:771-776.

Benavides-Piccione R, Ballesteros-Yañez I, DeFelipe J, Yuste R (2002) Cortical area and species differences in dendritic spine morphology. J Neurocytol 31:337-346.

Berkley J (1895) Studies on the lesions produced by the action of certain poisons on the nervecell. Med News 67:225-231.

Daily ME, Smith SJ (1996) The dynamics of dendritic structure in developing hippocampal slices. J Neurosci 16:2983-2994.

Freire M (1978) Effects of dark rearing on dendritic spines in layer IV of the mouse visual cortex. A quantitative electron microscopical study. J Anat 126:193-201.

Freire M (1992) Interactive computer-assisted coding, three-dimensional reconstruction, and quantitative analysis of neuronal perikarya, processes, spines and varicosities. J Neurosci Methods 10:331-349.

Gray EG (1959a) Electron microscopy of synaptic contacts on dendrite spines of the cerebral cortex. Nature 183:1592-1593.

Gray EG (1959b) Axo-somatic and axodendritic synapses of the cerebral cortex: an electron microscopic study. J Anat 93:420-433.

Grutzendler J, Kasthuri N, Gan WB (2002) Long-term dendritic spine stability in the adult cortex. Nature 420:812-816

Harris KM, Stevens JK (1989) Dendritic spines of CA1 pyramidal cells in the rat hippocampus: serial electron microscopy with reference to their biophysical characteristics. J Neurosci 9:2982-2997.

Harris KM, Jensen FE, Tsao B (1992) ThreeDimensional structure of dendritic spines and synapses in rat hippocampus (CA1) at postnatal day 15 and adult ages: implications for the maturation of synaptic physiology and longterm potentiation. J Neurosci 12:2685-2705.

Holtmat AJ, Trachtenberg JT, Wilbrecht L, Shepherd GM, Zhang X, Knott G, Svodoba K (2005) Transient and persistent dendritic

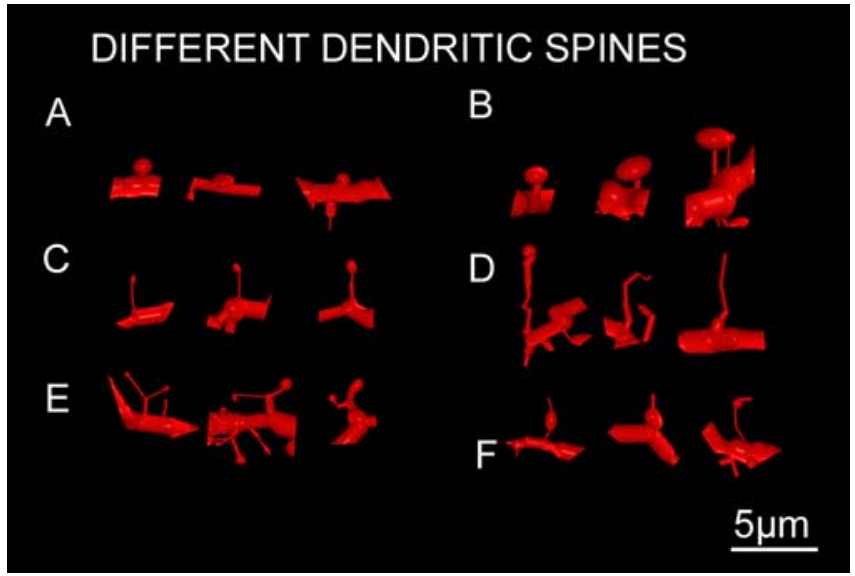

Figure 4. Different types of dendritic spines codified. $\boldsymbol{A}$, Sessile spines. $\boldsymbol{B}$, Mushroom spines. $\boldsymbol{C}$, Thin spines. D, Filopodia. $\boldsymbol{E}$, Branched spines. $\boldsymbol{F}$, Spines with spinules.

spines in the neocortex in vivo. Neuron 45:279-291.

Kasai H, Matsuzaki M, Noguchi J, Yasumatsu N, Nakahara H (2003) Structure-stabilityfunction relationships of dendritic spines. Trends Neurosci 26:360-368.

Lee KJ, Kim H, Kim TS, Park S, Rhyu IJ (2004) Morphological analysis of spine shapes of Purkinje cell dendrites in the rat cerebellum using high-voltage electron microscopy. Neurosci Lett 359:21-24.

Matsuzaki M, Ellis-Davies GC, Nemoto T, Miyashita Y, Iino M, Kasai H (2001) Dendritic spine geometry is critical for AMPA receptor expression in hippocampal CA1 pyramidal neurons. Nat Neurosci 4:1086-1092.

Nusser Z, Lujan R, Laube G, Roberts J, Molnar E, Somogyi P (1998) Cell type and pathway dependence of synaptic AMPA receptor number and variability in the hippocampus. Neuron 21:545-559.

Parnass Z, Tashiro A, Yuste R (2000) Analysis of spine morphological plasticity in developing hippocampal pyramidal neurons. Hippocampus 10:561-568.

Peters A (1987) Synaptic specificity in the cerebral cortex. In: Synaptic function (Edelman GM, Gall WE, Cowan WM, eds), pp 373-397. New York: Wiley.

Peters A, Kaiserman-Abramof IR (1970) The small pyramidal neuron of the rat cerebral cortex: the perikaryon, dendrites and spines. Am J Anat 127:321-356.

Ramón y Cajal S (1888) Estructura de los centros nerviosos de las aves. Rev Trim Histol Norm Patol 1:1-10.

Ramón y Cajal S (1889) Sobre las fibras nerviosas de la capa granulosa del cerebelo. Rev Trim Histol Norm Patol 1:107-118.
Ramón y Cajal S (1891) Sur la structure de l'écorce cérébrale de quelques mammifères. La Cellule 7:125-176.

Ramón y Cajal S (1894) Consideraciones generales sobre la morfología de la célula nerviosa, pp 1-15. Madrid: Moya.

Ramón y Cajal S (1896a) El azul de Metileno en los centros nerviosos. Rev Trim Micrográf Madrid 1:151-203.

Ramón y Cajal S (1896b) Las espinas colaterales de las células del cerebro teñidas por el azul de metileno. Rev Trim Micrográf Madrid 1:123-136.

Ramón y Cajal S (1899) Textura del sistema nervioso del hombre y de los vertebrados. Imprenta y Librería de Nicolás Moya, Madrid, 1899 Tomo I.

Ramón y Cajal S (1909) Histologie du systeme nerveux de l'homme et des vertebres. Paris: Maloine.

Ramón y Cajal S (1933) ¿Neuronismo o reticularismo? Las pruebas objetivas de la unidad anatómica de las células nerviosas. Arch Neurobiol 13:1-144.

Schikorski T, Stevens CF (2001) Morphological correlates of functionally defined synaptic vesicle populations. Nat Neurosci 4:391-395.

Špaček J, Hartmann M (1983) Three-dimensional analysis of dendritic spines. I. Quantitative observations related to dendritic spine and synaptic morphology in cerebral and cerebellar cortices. Anat Embryol (Berl) 167:289-310.

Trachtenberg JT, Chen BE, Knott GW, Feng G, Sanes JR, Welker E, Svoboda K (2002) Longterm in vivo imaging of experiencedependent synaptic plasticity in adult cortex. Nature 420:788-794 